
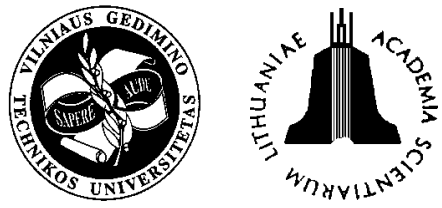

ISSN 1648-4142 print / ISSN 1648-3480 online TRANSPORT

www.transport.vtu.lt

\title{
LOGISTICS PARK DEVELOPMENT IN SLOVAK REPUBLIC
}

\author{
Marián Šulgan \\ Dept of Road and Urban Transport, University of Žilina, Univerzitná 1, 01026 Žilina, Slovakia. \\ E-mail:Marian.Sulgan@fpedas.utc.sk
}

Received 14 December 2005; accepted 9 May 2006

\begin{abstract}
The paper deals with the actual situation in the Slovak Republic concerning the logistics parks development. It presents the theoretical base of the logistics park development, i.e. the comparative analysis, SWOT analysis, transport infrastructure survey, marketing study and marketing plan for logistics park. It also presents the basic characteristic of logistics park, logistics chains and activities connected with the transport, logistics and goods distribution.
\end{abstract}

Keywords: transport, logistics, logistics park, logistics centre, freight transport.

\section{Introduction}

Nowadays, we are witnessing the deep structural changes in Europe. Globalisation processes determine not only transport but also all human activities. The objective of the European Commission's White Paper "European transport policy for 2010: time to decide" is to refocus Europe's transport policy on the demands and needs of its citizens. The White Paper proposes more than 60 measures to meet this challenge. The first of these measures is designed to shift the balance between modes of transport by 2010, by revitalising the railways, promoting maritime and inland waterway transport and linking up the different modes of transport. The principal objective of the EU's regional policy is to eliminate regional disparities and to promote integration and social cohesion. The Union seeks to use the policy to help the lagging regions to catch up, restructure declining industrial regions, diversify the economies of rural areas with declining agriculture and revitalise declining neighbourhoods in the cities.

Transport policy plays a major role in strengthening the economic and social cohesion of the European Union. Firstly, it helps reduce regional disparities, particularly by improving access to island and peripheral regions. It also has a beneficial effect on employment, by encouraging investment in transport infrastructure and assisting workers' mobility.

Žilina University together with the Žilina Municipality are involved in solving objectives of the international REDETRAL project (Regional Development and Transport Logistics - European best practice in the development of logistics parks). The project is financed by the European Union under the ERDF - Interreg IIIC East Community Initiative. The lead partner for REDETRAL is Břeclav Municipality (the Czech Republic) and involves the following partner organisations:

- City of Žilina (the Slovak Republic);

- NUTS III Region of Southern Moravia (the Czech Republic);

- South-East Regional Authority (Ireland);

- KLOK Competence Centre Logistics Kornwestheim Ltd. (Germany);

- $\quad$ AMAVE Union of Municipalities (Portugal);

- Municipal Co-operation Ratschendorf (Austria).

The overall objective of REDTRAL "is to develop a European Best Practice Approach to the development of logistics parks in view of the importance of sustainable traffic and transport solutions in the framework of regional development".

In the Slovak Republic, freight transport has changed rapidly and there are a lot of new logistics parks in the regional developing aims. The new logistics activities are presented as subsystems of corporate or logistics system of business association. The logistics structure contains bookings, material handling, spacing, stocks, storages, packing activities, customer service, transport, informational systems, etc. From the analysis of logistics companies the development in developed European countries resulted when attention was initially set on raw material deliveries in order to limit and minimize stocks, transfer of production from buffer stores to trading partners and consumers. 
Activities enabling the formation of present complex logistics chains were gradually assigned. Each transport chain can be the element of certain logistics chain thus becoming the organized sequence of procedures. Forwarding, which represents an important element of future logistics chains and enables the development of combined transport, plays an important role nowadays. It should be also understood that this new stage, which is directed at transmodality, is based on logistics.

\section{Logistics park development - theoretical base}

There are a few steps in the beginning of the logistics park development. The first step is to create the Comparative Analysis (profile) of the region. Each REDETRAL partner had to complete a questionnaire regarding their respective region that sought data and information under a number of headings. A copy of the Comparative Analysis questionnaire was issued to each partner organisation. The important part of the Comparative Analysis are the Socio-Economic Indicators - area $\left(\mathrm{km}^{2}\right)$, population, unemployment rate, principal economic sectors, etc. The next part of the Analysis is the SWOT Analysis - the sheet for each region was made with the main information about the Strengths, Opportunities, Weaknesses and Threats in the region. The final part of the Analysis is the Transport Infrastructure Survey - the transport network, motorways $(\mathrm{km})$, railways $(\mathrm{km})$, airports, international corridors, intermodal terminals, sea ports, etc.

The next step is to create the Marketing study of territory, based on effective approach including phases:

- Audit of territory;

- Determination of vision and objectives;

- Marketing strategy;

- Plan of implementation;

- Implementation and control.

Marketing plan for logistics park includes:

- Situation analysis of region - territory orientated for transport and logistics;

- Marketing objectives of transport and logistics solution: positive image, competitive advantage of region, attractiveness of regional labour market, development of new transport projects for new industrial parks, increasing of transport accessibility and transport quality, creation of logistics chains, etc.;

- Selection of segments for logistics solution: population of region, institutional units, industrial subjects, export markets, visitors of region;

- Elaboration of marketing plan - marketing mix of logistics park.
Among the key regional conditions for the development of logistics park we can rank the transport and infrastructure level, telecommunications (developments in information technology are seen as critical in the development of European logistics), energy costs and the likelihood of shortages, social infrastructure, labour force, markets, environmental issues (increasing attention to environmental issues in response to public concerns), land using and spatial planning.

Regional conditions dealt with at present have concentrated on those infrastructural items that "directly" impact on the successful development of logistics parks. However, perhaps equally as important are "quality of life" conditions that also determine the attractiveness of locations. People and, by association, companies and investment/development are often attracted to areas and regions where there is a vibrant social and cultural life, coupled with a wide range of services including education, healthcare and childcare facilities and ready access to entertainment and amenity facilities.

Logistics park should encourage intermodal transport. Intermodal transport involves the movement of goods in one and the same loading unit or vehicle that successively uses several modes of transport without handling of the goods themselves in changing modes.

Basic of Logistics Park (LP) characteristic:

- Point of the concentration of logistics flows and logistics operations;

- Concentrative node of the traffic flows;

- Centre of the customer - supplier chains effectively managed.

Logistics park is an exactly delimited domain including the activities connected with the transport, logistics and goods distribution. There is a working area for operators, traffic and logistics companies, the place for buildings and facilities within the logistics park, there is a concentration point of public facilities, services and access for all relevant companies. LP supports the multimodal transport and is established and managed by the one company.

Industrial production analysis and opportunities of logistics services brought information about the foods, beverages, textiles, footwear, electronics, white technicals (fridges, washers, cook ranges, etc.), tyres and machine products which are the most suitable piece-goods for logistics produced and manufactured in the Slovak Republic.

Selected commodities suitable for logistics and produced in the Slovak Republic are displayed in Fig 1. Black columns illustrate commodities of industrial production suitable for logistics park.

Demand for transport services results from commodity demand. Goods and commodity movement 


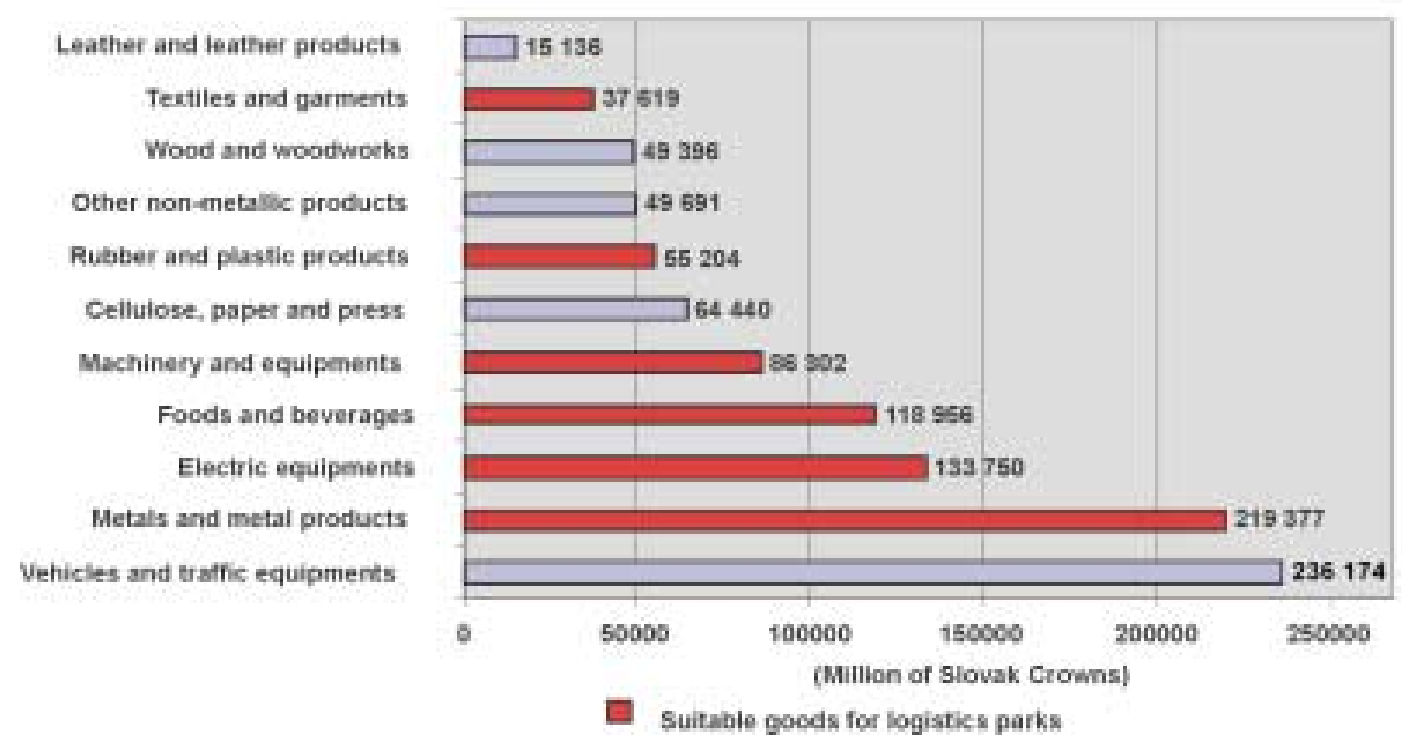

Fig 1. Industrial production in the Slovak Republic (in the year 2004) and selected commodities suitable for logistics parks

are characterized by freight transport principles, which are realized from manufacturers to dealers or consumers in required quantity, quality and delivery terms. Growth of customer demand for various kinds of goods creates pressure onto shopkeepers and requires to find optimal goods delivery chains by appropriate logistics solutions including freight transport services.

Logistics park allows the incoming of carriers, forwarders, logistics services, logistics industry, business organizations, governmental agencies, financial and insurance companies and other businessmen.

LP allows the connection of at least two modes of transport, and supports the synergetic effects by the cooperation projects of participating firms. The most significant clients of the logistics parks are the car production plants, the supermarket and hypermarket chains, the electronic industry and information technology industry.

There are a lot of differences among the LP conception, importance, range and characteristic features within Europe and also among the names of LP. For example there is a Freight Village in Great Britain, a Plate Forme Logistique in France, a Guterverkehrszentrum GVZ in Germany, an Interporto in Italy, a Logistik Centre and Cargo Centre in Austria, etc.

\section{Logistics parks in the Slovak Republic}

Logistics parks in the Slovak Republic are displayed in Table 1 . There is only one LP in operation. The other planned parks can exploit a lot of new in- ternational experiences according to the REDETRAL project. The strategic investors (Volkswagen, KIA Motors, etc.) need to have the modern and efficient Logistics parks.

Suggested localities for Žilina Logistics park by the REDETRAL project are displayed in Fig 2. The project is aimed for the European best practice in the development of logistics parks.

Table 1. Logistics parks in the Slovak Republic

\begin{tabular}{|l|l|}
\hline \multicolumn{1}{|c|}{ Locality name } & \multicolumn{1}{c|}{ Total area } \\
\hline Bratislava - Rača & $66600 \mathrm{~m}^{2}$ \\
\hline Bratislava Logistics Park & $300000 \mathrm{~m}^{2}$ \\
\hline Devínska N. Ves Logistics Park & $200000 \mathrm{~m}^{2}$ \\
\hline Logistics Park Trnava & $500000 \mathrm{~m}^{2}$ \\
\hline Logistics Park Trenčín & $1000000 \mathrm{~m}^{2}$ \\
\hline $\begin{array}{l}\text { Euro Logistics Park Lozorno } \\
\text { (in operation) }\end{array}$ & $100000 \mathrm{~m}^{2}$ \\
\hline
\end{tabular}

\section{Conclusions}

Locality relationship with the technical infrastructure networks must evaluate the traffic connections with the road and railway network, the existence of the build up of the duct, the build up of the sewarage, proximity of the gas line and the energetics network.

Further influences on the locality selection are the limits of the environment, strong points and weakness of the locality, possibilities of the locality potential, constraint and risks. 


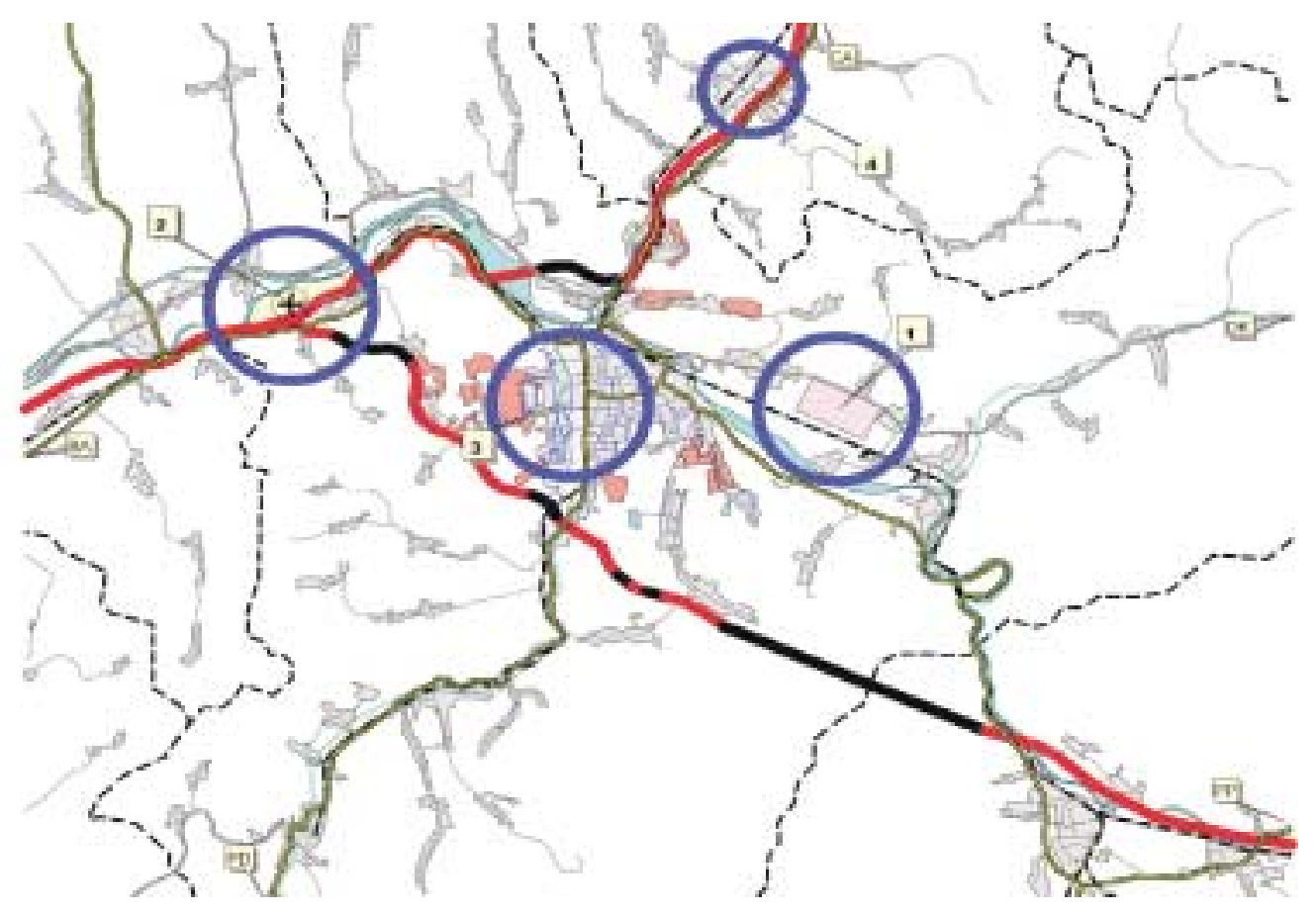

Fig 2. Logistics park localities in Žilina region: 1 - KIA Motors; 2 - Žilina airport; 3 - Industrial zone Žilina; 4 - Industrial zone Kysucké N. M.; CA - Cadca direction; DK - Dolný Kubín direction; PP - Poprad direction; $\mathrm{PD}$ - Prievidza direction; BA - Bratislava direction

There are a lot of opportunities for logistics centre and logistics services development in the Žilina region because this area is characterired by a huge industry development (existing machineries, chemical and textile enterprises, KIA Motors car factory and a lot of subsuppliers factories) and by increasing of the customers demand.

The European best practice approach to the development of logistics parks and know-how obtained by building logistics centres in the Slovak Republic should be utilized in building the Žilina Logistics centre. Reorganization of the freight transport is one of the important instruments for practical realization of logistics goals.

\section{References}

1. Sosedová, J.; Rievaj, V.; Dávid, A. Logistics in condition of inland river port. LOGISTICS 3/2005. Journal (Logistyka w warunkach śródladowego portu rzecznego. LOGISTYKA 3/2005. Czasopisimo). Poznań: ILM, 2005. ISSN 1231-5478 (in Polish).

2. Gnap, J. et al. Project REDETRAL (Regional Development and Transport Logistics) Co-financed by CIP Interreg IIIC. East Zone. Workshop in Žilina on June, 2005.

3. Šulgan, M., et al. Project VEGA 1/2615/05 Economic and qualitative changes and synergetic influences on transport and logistics area after Slovak integration into EU, Žilina University, 2005. 